\title{
Inhibition of Protein Tyrosine Kinases Impairs Axon Extension in the Embryonic Optic Tract
}

\author{
Terri Worley and Christine Holt \\ Department of Biology, University of California at San Diego, La Jolla, California 92093
}

The role of protein tyrosine kinase (PTK) activity in the development of the retinal projection was examined in vivo by applying inhibitors of cytoplasmic PTKs, herbimycin A and lavendustin $A$, to intact brain preparations of Xenopus embryos. The inhibitors were present during the period when retinal ganglion cell axons first navigate through the optic tract to reach their target, the optic tectum. A majority of inhibitor-treated retinal axons stalled at the beginning of the optic tract, leading to an $80 \%$ reduction in projection length at the highest doses. All inhibitor-treated axons that did extend into the optic tract exhibited normal pathfinding behavior. Tyrosine kinase assays of inhibitor-treated brains demonstrated that at doses at which retinal axon extension was severely impaired, PTK activity, including that of src family proteins, was reduced by $50-60 \%$. Consistent with the in vivo findings, PTK inhibitors reduced

Extracellular cues provide the exploring tip of the retinal axon, the growth cone, with the molecular information needed to properly extend in the optic pathway (Bixby and Harris, 1991; Holt and Harris, 1993; Chien and Harris, 1994). One possible mechanism by which these cues are transduced into meaningful signals is modulation of tyrosine phosphorylation. Phosphotyrosine is abundant in the process-rich layers of the embryonic chicken retina, optic tract, and optic tectum (Shores and Maness, 1989; Biscardi et al., 1991), and several receptor protein tyrosine kinases (PTKs) (Jelsma et al., 1993; Sajjadi and Pasquale, 1993; Takahashi et al., 1993; Cohen and Fraser, 1994; Escandon et al., 1994; Pasquale et al., 1994; Tcheng et al., 1994; Cheng et al., 1995; McFarlane et al., 1995) and cytoplasmic PTKs are expressed in the developing visual system, including the $s r c$ family members pp $60^{c-s r c}$, pp59c-fyn, and pp59c-yes (Sorge et al., 1984; Maness et al., 1990; Sugrue et al., 1990; Zhao et al., 1991; Ingraham et al., 1992; Bare et al., 1993; Bixby and Jhabvala, 1993).

src PTKs may transduce signals from receptors for molecules promoting neurite outgrowth that lack intrinsic tyrosine kinase activity. For example, stimulation of integrins results in an intracellular increase in tyrosine phosphorylation (Hirst et al., 1986; Guan et al., 1991; Kornberg et al., 1991; Guan and Shalloway,

\footnotetext{
Received Nov. 2, 1995; revised Dec. 17, 1995; accepted Dec. 19, 1995.

This work was supported by National Institutes of Health Grant N\$23780, the March of Dimes, and a Pew Scholars Award. We thank Elena Pasquale, Jocelyn Holasch, Tony Hunter, David Schlaepfer, Robert Steele, Darwin Berg and Phyllis Pugh for their generous sharing of materials and technical advicc. We also thank Bill Harris, David Rapaport, Wes Chang, Andreas Walz, Chi-Bin Chien, Lisa McNeill, Elena Pasquale, and Tony Hunter for critical input to this project and to the preparation of this manuscript.

Correspondence should be addressed to Dr. Christine Holt, Department of Biology 0366, 9500 Gilman Drive, University of California at San Diego, La Jolla, CA 92093.

Copyright 1996 Socicty for Neuroscience $0270-6474 / 96 / 162294-13 \$ 05.00 / 0$
}

neurite outgrowth from cultured retinal neurons by $70-80 \%$. This contrasts with the strong enhancement of outgrowth induced by the same inhibitors in cultured chick ciliary ganglion neurons and suggests that the mediation of outgrowth by PTK activity may vary in different neuronal types. Inhibitor-treated growth cones cultured on laminin were larger than normal, suggesting that tyrosine phosphorylation can modulate growth cone-substrate adhesive interactions. Our results in vivo and in vitro provide complementary evidence that retinal axon outgrowth is inhibited by pharmacological blockers of PTK activity and indicate that inhibitor-sensitive PTKs normally play a role in promoting retinal neurite extension.

Key words: retinotectal projection; axon guidance; $p p 60^{\mathrm{c}} \mathrm{sc}$, tyrosine kinase inhibitors; growth cone; neurite elongation

1992), which is at least partly attributable to the stable association and activation of pp60 $60^{-s \%}$ and another PTK, pp125 ${ }^{\mathrm{FAK}}$ (Lipfert et al., 1992; Fox et al., 1993; Huang et al., 1993; Cobb et al., 1994; Schaller et al., 1994; Schlaepfer et al., 1994; Shattil et al., 1994; Xing et al., 1994). Cerebellar neurons from src-minus mice extend shorter neurites than controls on L1 substrates (Ignclzi ct al., 1994), and N-CAM-mediated neurite outgrowth is impaired in neurons from fyn-minus mice (Beggs et al., 1994). Finally, the cadherin-catenin cell adhesion system is inhibited by $v$-srcmediated tyrosine phosphorylation (Matsuyoshi et al., 1992; Behrens et al., 1993; Hamaguchi et al., 1993a). Thus, pp60 ${ }^{c-s r c}$ and pp $59^{-f y n}$ are implicated in the signaling pathways of molecules important for axon elongation.

The addition of PTK inhibitors to cultured neurons has yielded diverse effects on neurite outgrowth. Embryonic chicken ciliary ganglion cells sprout more and longer neurites in the presence of genistein and lavendustin A (Bixby and Jhabvala, 1992), suggesting that PTK activity negatively modulates neurite elongation. In contrast, N-CAM-, N-cadherin-, and L1-stimulated growth of rat ccrebellar neurons is inhibited by an erbstatin analog and tyrphostins 23 and 25 (Williams et al., 1994), indicating that PTKs promote neurite clongation on these substrates. Finally, neurite outgrowth from $\mathrm{PC} 12$ cells stimulated by nerve growth factor (NGF) is increased by genistein and lavendustin $\Lambda$ (Miller et al., 1993) but blocked by the more general protein kinase inhibitors K-252a and K-252b (Hashimoto, 1988; Knusel and Hefti, 1992; Knusel et al., 1992). Thus, the precise role of PTK activity in the initiation and extension of neurites from differentiating neurons is not well understood.

We asked whether PTK activity is involved in mediating the extension of retinal axons through the optic tract in vivo by pharmacologically inhibiting PTK activity in the intact embryonic 
brain. We also applied PTK inhibitors to embryonic retinal neurons in culture. Our observations show that herbimycin $\mathrm{A}$ and lavendustin A impair the development of retinal projections in vivo and retinal neurite outgrowth in vitro. Treatment with these inhibitors in vivo, however, does not appear to induce pathfinding errors in the optic tract.

\section{MATERIALS AND METHODS}

Embryos. Embryos were obtained from our Xenopus laevis breeding colony at the University of California, San Diego. Embryos from hormone-induced matings were maintained in 10\% Holtfreter's solution and raised at varying temperatures $\left(14,17\right.$, and $\left.25^{\circ} \mathrm{C}\right)$ to obtain a range of developmental stages (Nieuwkoop and Faber, 1967).

PTK inhibitors and antibodies. Herbimycin A and lavendustin A (Gibco, Grand Island, NY) were resuspended in dimethylsulfoxide (DMSO) and stored in aliquots at $-20^{\circ} \mathrm{C}$. Lavendustin A was also obtained from Research Biomedicals (Natick, MA). An anti-phosphotyrosine monoclonal antibody, PY20, and a polyclonal antibody against Mek-1 and -2 were purchased from Transduction Laboratories (Lexington, KY). A polyclonal anti-phosphotyrosine antibody, anti-PY, was a gift from Dr. Elena Pasquale (La Jolla Cancer Research Foundation, La Jolla, CA). A monoclonal antibody against the middle and low molecular weight neurofilament proteins, RMO270.7, was a gift from Dr. Virginia Lee (University of Pennsylvania, Philadelphia, PA). A polyclonal antibody against $c-s r c$ and a control peptide were purchased from Santa Cruz Biotechnology (Santa Cruz, CA).

Exposed brain preparation. This method gives experimental access to the developing optic tract and has been described previously (Chien et al., 1993; McFarlane et al., 1995). Stage 32 embryos were placed in $100 \%$ modified Ringer's solution (MR; pH 7.5) with $1 \%$ Fungi-Bact (UCSD Core Culture Facility) and $50 \mathrm{\mu g} / \mathrm{ml}$ gentamicin sulfate (Gemini, Calabasa, CA) and anesthetized with MS222 (ethyl-3-amino benzoate methanesulfonic acid salt, Aldrich, Milwaukee, WI; $0.4 \mathrm{mg} / \mathrm{ml}$ ). The left side of the embryonic brain was exposed to the bathing medium by removing the right eye and the skin epidermis overlying the diencephalon, the midbrain and the anterior part of the hindbrain. Neither the contralateral retina nor the optic chiasm area was exposed. After surgery, embryos were placed in $100 \%$ MR with $0.3 \%$ DMSO in the presence or absence of PTK inhibitors. Embryos were kcpt at room tempcrature for 18-24 hr in the dark (PTK inhibitors are light-sensitive) until they reached stage 39.

Quantitation of retinal projection lengths. The retinal projection was visualized by anterograde horseradish peroxidase (HRP Type VI-A peroxidase, Sigma, St. Louis, MO) labeling as described previously (Harris et al., 1985). Embryos were fixed in $4 \%$ paraformaldehyde in $0.1 \mathrm{~m}$ phosphate buffer for $4-24 \mathrm{hr}$, with overnight fixations done at $4^{\circ} \mathrm{C}$. Fixed brains were removed, reacted with diaminobenzidine (Sigma), dehydrated in an alcohol series, and mounted in Permount (Fisher Scientific, Tustin, CA). Brains and projections were drawn at $16 \times$ using a camera lucida attachment on a Leitz microscope. Drawings were scanned using a Hewlett Packard ScanJet II, and computer images of the brains were compensated for size and orientation variations using macros previously developed for the National Institutes of Health Image program (Chien ct al., 1993). Projection lengths in the contralateral diencephalon were measured from the point of entry into the optic tract (the ventral diencephalon) to the most distal point reached in the pathway. Inhibitortreated projections often comprised a thick mass of short axons with a few sparse axons extending further along the pathway. To reflect accurately the behavior of the majority of axons, sparse longer axons were not included in the length calculations unless four or more were present.

Analysis of pathfinding. Scanned images of control specimens from the herbimycin A experiments were used to create a composite image of a control brain and projection. Computer manipulations of the images were performed using previously developed macros in National Institutes of Health Image (Chien et al., 1993). Each sample image was aligned to the same orientation, and samples that could not be aligned because of unclear identification of brain landmarks were omitted, leaving a total of 30 specimens. The separate images were combined into a single image, with darker gray colors corresponding to regions of greater overlap. A similar composite was made of 23 specimens treated with $1.3 \mu \mathrm{M}$ herbimycin A. For comparison of the composite projections, an outline of the control composite projection was positioned in the appropriate location on the treated image.

Immunohistochemistry. Brains were dissected from experimental embryos after overnight fixation in $4 \%$ paraformaldehyde in $0.1 \mathrm{~m}$ phosphate buffer at $4^{\circ} \mathrm{C}$ and processed for immunocytochemistry as whole mounts. Incubations with the PY20 antibody $(3 \mu \mathrm{g} / \mathrm{ml})$ were done overnight at $4^{\circ} \mathrm{C}$ and, to control for specificity, some brains were preincubated with $O$-phospho-L-tyrosine (2 mM/ $\mu$ g PY20; Sigma). Antibodies were diluted in PBS with $1 \%$ Triton $\mathrm{X}-100$ and $0.4 \%$ bovine serum albumin (BSA; fraction $\mathrm{V}$, Sigma), and 5-10\% goat serum was added to block nonspecific binding. A TRITC-conjugated secondary antibody was used (Jackson ImmunoResearch, West Grove, PA), and the brains were mounted in p-phenylene diamine (pPD glycerol, Sigma). Images of immunolabeled brains were taken with an SIT-650 (Dage MTI) camera mounted on a Nikon Optiphot-2 microscope and digitized in a Macintosh IIfx (Apple Computer, Cupertino, CA) as described previously (Chien et al., 1993). The same magnification and exposure time were used for each sample, and gray values were determined using National Institutes of Health Image macros. Dissociated cultures were stained as above using less $(0.3 \%)$ Triton X-100.

$I^{35}$ S/methionine labeling and trypan blue staining. Control embryos, inhibitor treated embryos, and embryos treated in $12 \mu \mathrm{g} / \mathrm{ml}$ cycloheximide for $1 \mathrm{hr}$ were incubated for $3 \mathrm{hr}$ in $1 \mathrm{mCi} / \mathrm{ml}\left[{ }^{35} \mathrm{~S}\right]$ methionine (specific activity, >1000; ICN Radiochemicals, Costa Mesa, CA). Brains were removed and homogenized with a Dounce homogenizer in PBS with $0.1 \mathrm{mg} / \mathrm{ml} \mathrm{BSA}$, and proteins were precipitated on ice for $30 \mathrm{~min}$ in a final concentration of $10 \%$ trichloroacetic acid. Protein precipitates were vacuum-filtered onto Whatman filter paper and counted in a scintillation counter.

Trypan blue staining was performed by placing live embryos with exposed brains in $0.5 \%$ Trypan blue (Sigma) for 3-5 min. Brains were mounted in PBS, and blue cells were counted from the forebrain to the hindbrain in the superficial layers of the neuroepithelium.

In vitro tyrosine kinase assay. Exposed brains treated for $4-5 \mathrm{hr}$ with PTK inhibitors were dissected and placed in protease inhibitor buffer [0.1 $\mathrm{M} \mathrm{NaCl}, 10 \mathrm{~mm}$ Tris, pH 7.6, 1 mm EDTA, $\mathrm{pH} 8,2.5 \%$ Nonidet P-40, 1 $\mathrm{mM}$ sodium orthovanadate (Sigma), 0.2 trypsin inhibitor units $/ \mathrm{ml}$ aprotinin (Sigma), $1 \mathrm{~mm}$ phenylmethylsulfonyl fluoride (Sigma), and $25 \mu \mathrm{g} / \mathrm{ml}$ lcupeptin (Sigma)]. Samples were homogenized by pipetting, and aliquots of supernatant were removed after centrifugation to perform a protein concentration assay (Bio-Rad DC Protein Assay, Bio-Rad, Richmond, CA). In vitro PTK reactions and ELISA assays were performed in duplicate using the Genius Tyrosine Kinase Assay Kit (nonradioactive) from Boehringer Mannheim (Indianapolis, IN) according to their protocol. After $3 \mathrm{~min}$, the ELISA reaction was quenched by adding $100 \mu \mathrm{l}$ of $1 \%$ SDS to each well, and the absorbance at $405 \mathrm{~nm}$ was read.

Western blot analysis. Brains of cxpcrimental embryos were placed immediately on ice in a modified RIPA buffer (Schlaepfer et al., 1994). Samples were homogenized by repeated pipetting and centrifuged, and protein concentration assays (Bio-Rad) were performed on aliquots of the supernatants. Some samples were treated for $30 \mathrm{~min}$ with alkaline phosphatase (Pharmacia, Alameda, CA) at a concentration of $2 \mathrm{U} / 50 \mu \mathrm{l}$. SDS-sample buffer was added, and samples were boiled $4 \mathrm{~min}$ before being loaded and run on a $7.5 \%$ SDS-polyacrylamide gel (Laemmli, 1970). Proteins were transferred to nitrocellulose (Towbin et al., 1979), and membranes were stained with amido black to confirm equal loading of protein. Membranes were destained, blocked overnight in 3\% BSA in Tris-buffered saline (TBS), and incubated for $34 \mathrm{hr}$ in $3 \mu \mathrm{g} / \mathrm{ml}$ anti-PY or the same concentration of antibody preincubated with 10 times the concentration of $O$-phospho-L-tyrosine. For anti-c-src and MEK- 1 and -2 staining, membrancs were blocked in $5 \%$ nonfat milk in TBS, and the antibodies were used at a concentration of $1 \mu \mathrm{g} / \mathrm{ml}$. After washing in TBS, the membranes were incubated in protein A peroxidase $(1 \mathrm{mg} / \mathrm{ml} \mathrm{stock}$ solution, Sigma), which was diluted 1:5000 in 3\% BSA in TBS for 1-2 hr. The staining was detected with ECL solutions according to the manufacturer's protocol (Amersham, Arlington Heights, IL) using Hyperfilm (Amersham). Densitometry was performed by scanning the films using a Hewlett Packard ScanJet II and measuring gray levels written in National Institutes of Health Image.

Dissociated Xenopus retinal cultures. Eye primordia from stage 25-27 embryos were dissociated and cultured as described previously (Harris and Messersmith, 1992) on coverslips coated with $1 \mathrm{mg} / \mathrm{ml}$ poly-Lornithine (Sigma) and $10 \mu \mathrm{g} / \mathrm{ml}$ mouse laminin [Gibco, Sigma, and Upstate Biotechnology (Lake Placid, NY)]. Culture medium was $60 \%$ L15 containing $10 \%$ fetal bovine serum, $1 \%$ embryonic extract, $1 \%$ Fungi-Bact (Irvine Scientific, Irvine, CA), and 0.33\% DMSO with or without a PTK inhibitor. Cultures were grown in the dark at room temperature, fixed overnight at $4^{\circ} \mathrm{C}$ in $2 \%$ paraformaldehyde, stained with $0.2 \%$ toluidine blue (Sigma), and mounted in glycerol. Drawings of 
individual neurons were made using a $40 \times$ phase objective and a camera lucida attachment. Measurements were made on cells identified as retinal ganglion cells based on their rounded morphology, size, and neurofilament-positive staining (RMO270.7 antibody). For the data presented, neurites were measured individually from the edge of the cell body to the most distal tip of the growth cone or axon if there was no growth cone. If a cell had two processes, each was measured separately. For branched processes, the longest continuous length was measured and the short branch was not included. Although not presented, the total neurite length from each cell was also measured in two experiments. The results for both methods of quantitation (individual length and total length) were similar. Camera lucida drawings of growth cones were made on a Zeiss Photomicroscope (Thornwood, NY) at $100 \times$ magnification. The filopodia were identified and counted as described previously (Holt, 1989). The width of the growth cone was determined by averaging four to eight spaced measurements across the dimension perpendicular to the axon. The length was measured as the longest dimension from the base of the growth cone thickening to the lamellar tip in a direction parallel to the axon.

Chick ciliary ganglion cultures. Ciliary ganglia from embryonic day 8 chicks were dissected and dissociated with trypsin as described previously (Nishi and Berg, 1981). They were plated at a density of 1.5 ganglia per culture on laminin-coated coverslips and cultured in Eagle's minimal essential medium containing $10 \%$ fetal horse serum, $3 \%$ embryonic chick eye extract (Nishi and Berg, 1981), and 0.33\% DMSO with or without a PTK inhibitor. Cultures were incubated at $37^{\circ} \mathrm{C}$ for $4 \mathrm{hr}$, then fixed in $4 \%$ glutaraldehyde and $5 \%$ sucrose in PBS for $3 \mathrm{hr}$ at $4^{\circ} \mathrm{C}$. Cultures were stained in $0.2 \%$ toluidine blue, mounted in glycerol, and examined with bright-field microscopy. Individual neurons were drawn using a camera lucida, and neurite lengths were quantitated as described previously (Bixby and Jhabvala, 1992).

\section{RESULTS}

\section{PTK inhibitors reduce the length of retinal projections}

To investigate whether PTKs modulate the extension of retinal axons in vivo, the PTK inhibitors herbimycin $\mathrm{A}$ and lavendustin $\Lambda$ were bath-applied to the diencephalon and midbrain during the period when axons first navigate the optic pathway. We used the exposed brain preparation that allows reagents direct access to the intact optic pathway as the retinal axons extend through it to their target (Chien et al., 1993; McFarlane et al., 1995). Briefly, the skin epidermis and eye were removed from the left side of the head of stage 32 embryos, exposing the underlying optic tract and tectum but not the contralateral retina or midline chiasm. At this stage of development, pioneering retinal axons from the contralateral eye have crossed the chiasm and are just beginning to enter the ventral optic tract. The growth cones are positioned very close $(\sim 10 \mu \mathrm{m})$ to the pial surface (Holt, 1989). Operated embryos were incubated in media in the presence or absence of PTK inhibitors until stage 39 , by which time the retinal projection has normally reached the optic tectum (Holt, 1984). The projections were visualized by anterograde transport of horseradish peroxidase (Harris et al., 1985; Cornel and Holt, 1992).

Embryos incubated in herbimycin A or lavendustin A appeared healthy and developed at a rate similar to control embryos; however, the retinal projections of the experimental groups were markedly shorter. In control embryos, 3-4 hr after brain exposure (stage 33/34), the leading retinal axons extended $\sim 100 \mu \mathrm{m}$ along the ventral part of the optic tract (Fig. $1 A$ ) and, by stage 39, 12-18 hr after exposure, retinal projections extended the full length of the optic tract and into the optic tectum (Fig. 1B). This contrasts with the phenotype observed for hoth herbimycin A- and lavendustin A-treated projections, where a majority of the retinal axons failed to extend much beyond the point of entry into the ventral optic tract (Fig. $1 C, D$ ). At the brain entry point and at the optic chiasm, areas that were not surgically exposed to the drug, the projections of control and treated embryos were similar in size and thickness (data not shown), indicating that axon growth was not affected in these areas. The average length of control projections in the contralateral diencephalon was $270 \mu \mathrm{m}$, whereas the average length of projections treated with the highest concentrations of the inhibitors was $50 \mu \mathrm{m}$ (Fig. 2). This $80 \%$ reduction in projection length demonstrates that PTK inhibition impairs axon elongation in vivo.

\section{Reduction in projection length is dose-dependent}

$A$ range of concentrations was tested for herbimycin $A$ and lavendustin A to determine their effective dose. The projection length was found to decrease with increasing concentrations of both drugs (Fig. 2). Maximal inhibition of growth was obtained with herbimycin $\mathrm{A}$ at $1.8 \mu \mathrm{M}$, and concentrations higher than this did not produce an additional decrease in projection length (data not shown). Lavendustin A also clicitcd a dose-dependent response although, surprisingly, lavendustin A from different commercial sources produced comparable effects at a different range of concentrations (Fig. 2).

\section{Effects of herbimycin $A$ are not attributable to toxicity}

To address the possibility that the inhibitory effects of herbimycin A on axon growth were altributable simply to a general toxicity of the drug, we performed three different experiments. First, we checked whether the effects of the drug were reversible. After an initial $8 \mathrm{hr}$ exposure to herbimycin A (stage 32 to 35/36), embryos incubated in inhibitor-free solution until stage 39. As shown in Figure 3, the average projection length of these embryos was intermediate between continuously treated and untreated controls, indicating recovery in vivo. This experiment does not show that the effects were reversed in individual axons, however, because new axons could have entered the optic tract after removal of the drug. Previous studies using cultured cells have documented the reversibility of herbimycin A (also see in vitro data in present study) and suggest that the recovery is attributable to de novo synthesis of the target PTKs (Uehara et al., 1989; Garcia et al., 1991).

Second, we evaluated the rate of protein synthesis in the inhibitor-treated brains by measuring the levels of incorporation of $\left[{ }^{35} \mathrm{~S}\right]$ methionine. The rate of protein synthesis in control and treated brains was found to be similar and contrasted with significantly lower levels seen in brains treated with cycloheximide (control brains: $1.2 \times 10^{5} \pm 2.8 \times 10^{4} \mathrm{cpm}, n=5$; herbimycin A: $1.2 \times 10^{5} \pm 2.2 \times 10^{4} \mathrm{cpm}, n=4$; cycloheximide: $3.5 \times 10^{4} \pm 6.1$ $\times 10^{3} \mathrm{cpm}, n=5$ ). The retina was not assayed because sectioned material of inhibitor-treated embryos showed morphologically normal, mitotically active retinae that retained phosphotyrosine immunoreactivity (data not shown) and our previous studies have indicated that reagents applied to the brain have little or no access to the contralateral retina (Chien et al., 1993; McFarlane et al., 1995).

Third, possible increases in cell death in the exposed brain tissue were evaluated using trypan blue, a dye that is excluded from live cells (Durkin et al., 1979). After exposure to $1.8 \mu \mathrm{M}$ herbimycin A for 12-18 hr, brains were stained with trypan blue and the number of labeled cells counted in the exposed area of the brain. The average number of stained cells present in the exposed side of inhibitor-treated brains $(107 \pm 15 ; n=10)$ was not significantly different ( $p<0.05$, one-tailed $t$ test) from that found in control exposed brains $(80 \pm 15 ; n=9)$. These cells were sparsely scattered through the forebrain and midbrain regions, and their number represents a small fraction (probably $<1 \%$ ) of the total number of cells comprising this area. Thus, effects on 

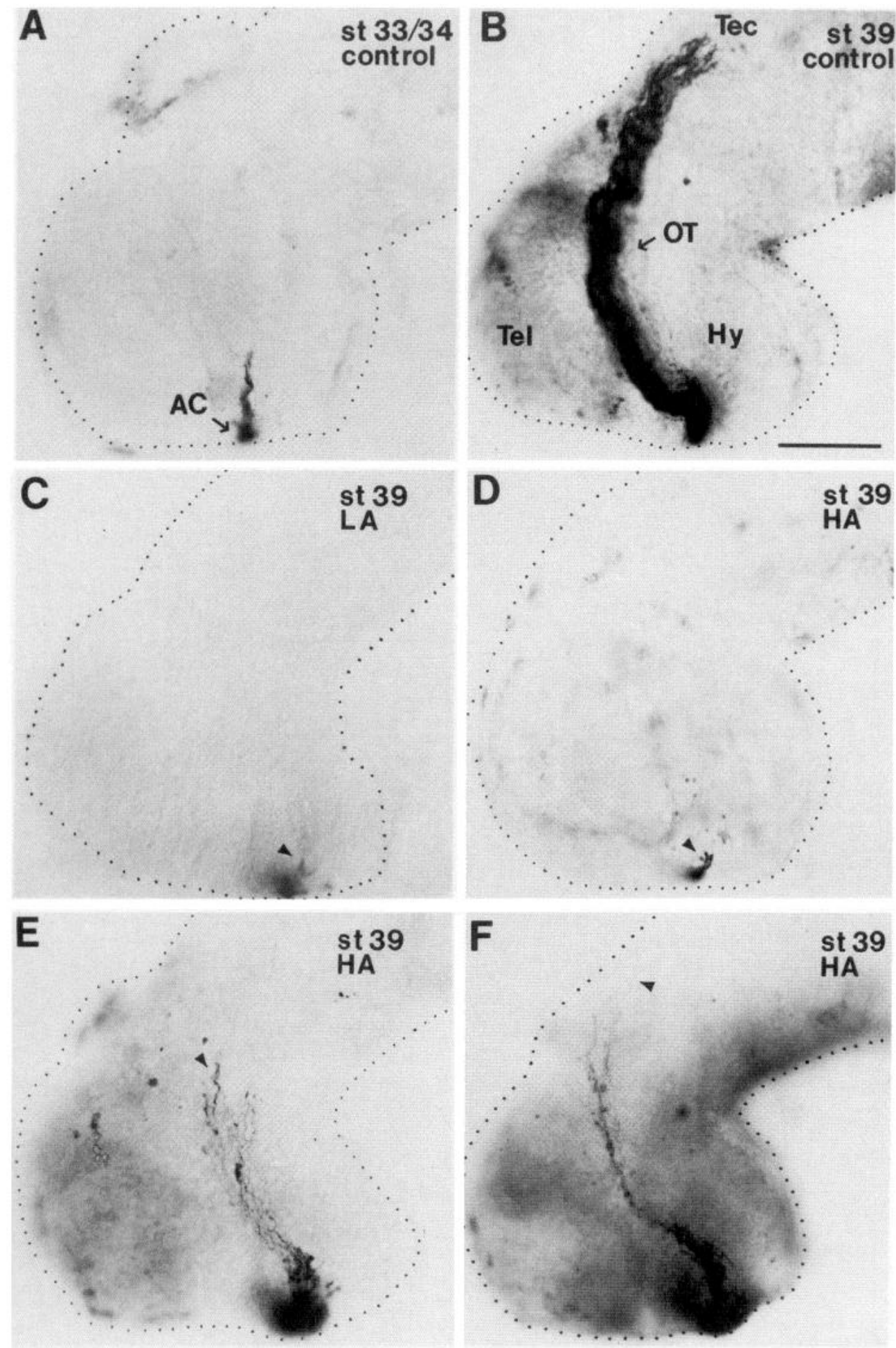

Figure 1. PTK inhibitors impair the development of the retinal projection. Lateral views of whole-mount brains showing horseradish peroxidase-filled retinal projections of untreated and treated brains. $A$, Stage 33/34 control brain. Axons from the contralateral eye that have grown across the chiasm (perpendicular to the plane of view) appear as a densely stained bundle at the edge of the ventral diencephalon $(A C$, anterior edge of chiasm). Leading retinal axons have entered the base of the optic tract and are heading dorsally in the ventral diencephalon. $B-F$, Brains were exposed at stage 32 , just before axons begin to enter the optic tract. $B$, Stage 39 exposed control brain showing the normal retinal projection that courses through the diencephalon forming the optic tract $(O T)$ and reaches the optic tectum (Tec). Tel, Telencephalon; $H y$, hypothalamus. $C, D$, Stage 39 brains treated with $100 \mu \mathrm{M}$ lavendustin A $($ Gibco; $C$ ) and $1.8 \mu \mathrm{M}$ herbimycin A $(D)$. The dense HRP stain at the anterior edge of the chiasm indicates that retinal axons have extended across the unexposed chiasm. The arrowheads point to axons that have entered the optic tract for a short distance; the entire projection ends at the entry point into the ventral optic tract. $E, F$, Stage 39 embryos treated with $1.8 \mu \mathrm{M}$ herbimycin A showing fibers that have advanced further than the rest of the projection. Fibers extend into the mid-optic tract in $E$, and two or three fibers reach the optic tectum in $F$. There are no apparent pathfinding deviations in either sample. Dorsal is up, and anterior is to the left. Scale bar, $100 \mu \mathrm{m}$. axon elongation in the tract cannot be attributed to elevated cell death in the substrate pathway. Together, these three assays provide strong evidence that inhibition of axon elongation in the optic tract is not attributable to nonspecific drug toxicity.

\section{PTK activity and levels of tyrosine phosphorylation are altered}

Both herbimycin A and lavendustin A have been shown to reduce the amount of PTK activity in cultured cells and in biochemical assays (Uehara et al., 1986, 1989; Onoda et al., 1989, 1990; Fukazawa et al., 1990, 1991; Uehara and Fukazawa, 1991). To examine the effectiveness of these drugs at inhibiting PTK activity in intact embryonic CNS tissue, an in vitro kinase assay was performed on crude lysates of whole brains that were first exposed intact to herbimycin A for $4 \mathrm{hr}$. The substrates for the PTKs were the biotinylated $\operatorname{cdc} 2(6-20)$ and the gastrin-17 peptides. Each peptide contains a consensus sequence for tyrosine phosphorylation, with the $\operatorname{cdc} 2(6-20)$ sequence being relatively specific for phosphorylation by src family PTKs (Cheng et al., 1992). The gastrin-17 sequence is less specific and is phosphorylated by a wide variety of PTKs in vitro (Baldwin et al., 1983). After the kinase reaction, tyrosine phosphorylation of the peptides was 

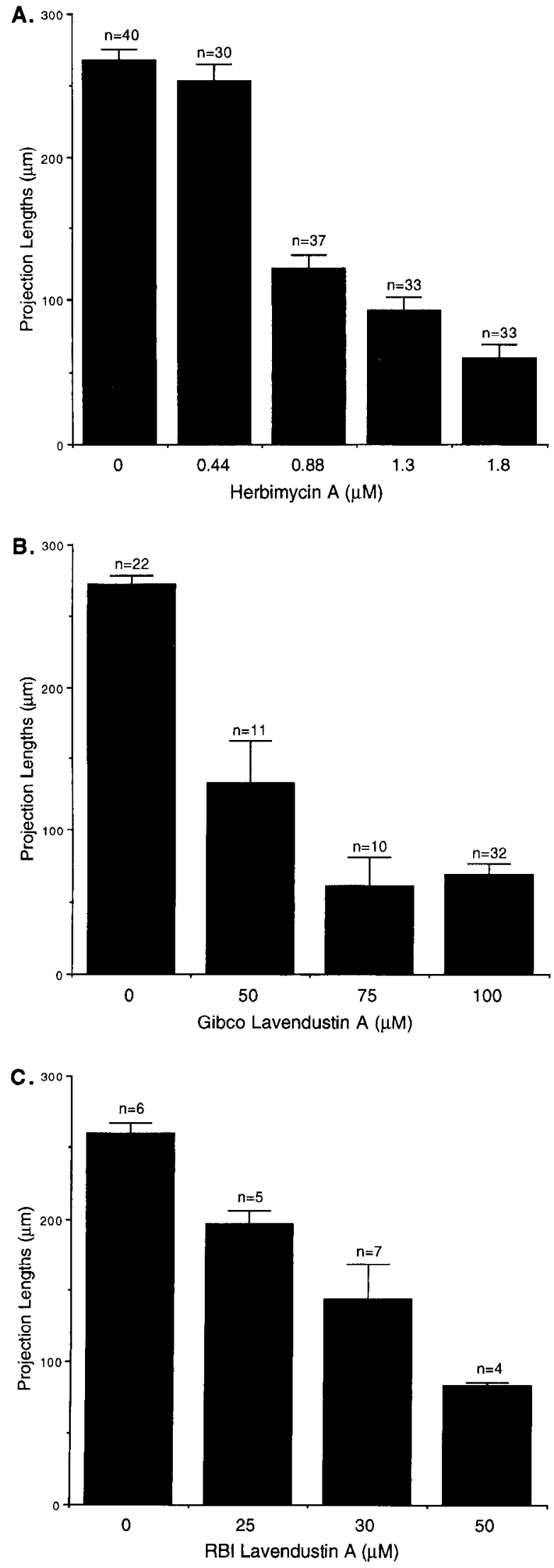

Figure 2. Dose-dependent decrease in projection length with PTK inhibitors. Retinal projection lengths plotted as a function of increasing concentrations of PTK inhibitors. $A$, Herbimycin A. $B$, Lavendustin A (Gibco). C, Lavendustin A (RBI). quantified with an ELISA assay using an anti-phosphotyrosine antibody, and the results demonstrated a significant decrease in tyrosine phosphorylation for both peptides with respect to control lysates (Fig. $4 A, B$ ). The reactions were performed in duplicate, and an average of three experiments gave a reduction in tyrosine phosphorylation of $66 \pm 18 \%$ with the cdc2(6-20) peptide and an average reduction of $52.7 \pm 3.9 \%$ for reactions using the gastrin-17 peptide. Control samples lacking ATP averaged a $93 \%$ reduction in phosphorylation compared with control reactions (data not shown). In addition, the amount of phosphorylation from lysates of brains that were exposed to herbimycin A during the bath only, or were exposed continuously both in the bath and in the kinase reaction, was compared and found not to be significantly different. In one experiment, sample homogenates were obtained from embryos treated with $50 \mu \mathrm{m}$ lavendustin A (Rcsearch Biomedicals). When compared with controls, these samples had $39 \%$ less tyrosine phosphorylation on the cdc2(6-20) peptide and $26 \%$ less on the gastrin-17 peptide (data not shown), suggesting that at this concentration lavendustin A may not be as effective as herbimycin A. However, this assay demonstrates that both drugs gain access to the tissue and inhibit PTK activity. In the case of $1.8 \mu \mathrm{m}$ lerbinycin $\mathrm{A}$, a $4 \mathrm{hr}$ exposure results in an $\sim 50-60 \%$ decrease in tyrosine phosphorlyation on two peptide substrates.

To demonstrate that herbimycin A effectively alters the levels of tyrosine phosphorylation in the brain, we compared the profile of tyrosine-phosphorylated proteins in control and PTK inhibitortreated brain homogenates using Western blot analysis. Lanes containing exposed control samples had 12 reproducible bands ranging in size from $\sim 180$ to $28 \mathrm{kDa}$ (Fig. $4 C$ ). After PTK inhibitor treatment, at least eight of the bands had a visible decrease in phosphotyrosine staining (approximate sizes 180, 115, $95,90,85,60,46$, and $40 \mathrm{kDa}$ ), and one band, at $\sim 28 \mathrm{kDa}$, showed an increase in staining intensity. The average reduction in optical density after densitometric tracing was $40 \pm 8 \%$ for the lane treated with herbimycin $A$ and $30 \pm 15 \%$ for the lane treated with lavendustin $A$. The staining was specific, because it could be blocked by competition with the peptide $O$-phosplio-L-tyrosine or by treatment of the lysates with alkaline phosphatase (data not shown). The $60 \mathrm{kDa}$ phosphotyrosine band observed to be sensitive to the inhibitors is the same molecular size as the PTK src. Consistent with this, when the blot was probed with an antibody against $\mathrm{pp} 60^{c-s r}$ (which is known to have some cross-reactivity to pp $60^{c \text { yes }}$ and $\mathrm{pp} 59^{c-f y n}$ ), a prominent band at $60 \mathrm{kDa}$ was labeled (Fig. $4 D$ ).

\section{Inhibitor-sensitive pattern of phosphotyrosine immunoreactivity}

To assess the spatial reduction in tyrosine phosphorylation, we examined exposed whole-mount brains by immunofluorescence with the PY20 anti-phosphotyrosine antibody. Control embryos exhibited a distinct pattern of phosphotyrosine immunoreactivity in the brain during embryonic development that was blocked by $O$-phospho-L-tyrosine (data not shown). The tract of the postoptic commissure (TPOC) is an early developing axonal tract in the diencephalon (Easter and Taylor, 1989; Cornel and Holt, 1992), and at stages 33/34-35/36 the TPOC and other developing axon tracts stain brightly (Fig. $5 A$ ). After exposure to herbimycin A or lavendustin $A$, the intensity of staining in the axon tracts was diminished (Fig. 5B). To quantitate the amount of reduction, computer images of six herbimycin A-treated and four control immunolabeled brains were captured, and the average gray values 
A. Controls

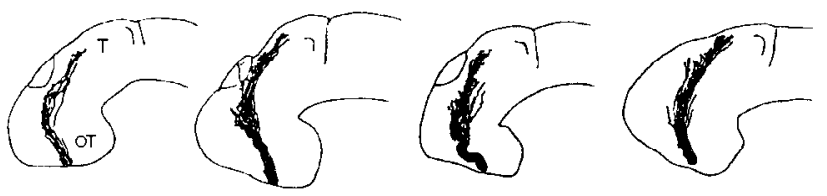

B. Herbimycin A
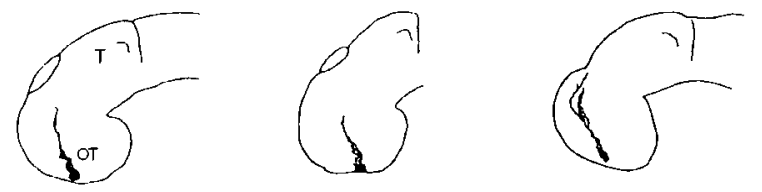

C. Recovery
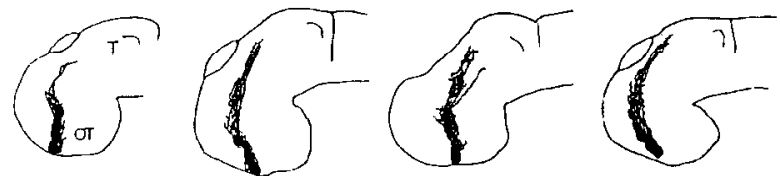

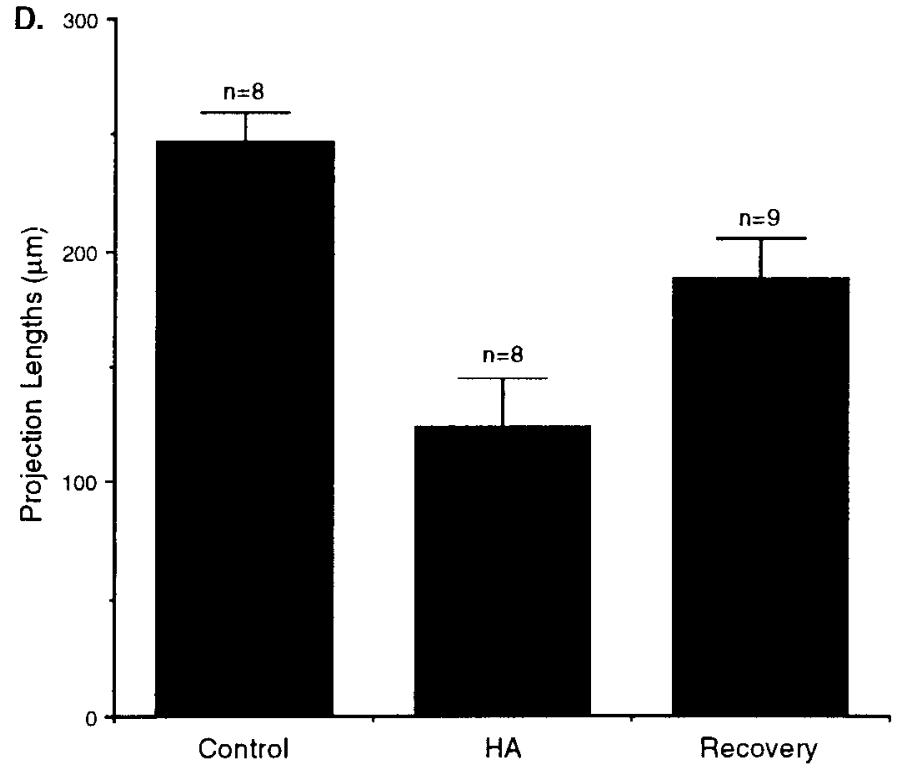

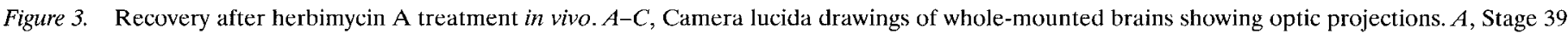

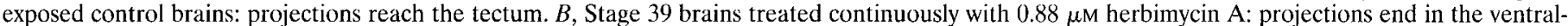

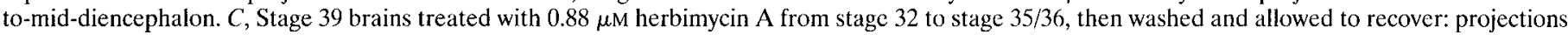
end in the dorsal optic tract or tectum. $T$, Optic tectum; $O T$, optic tract. $D$, Quantitation of projection lengths.

in the forebrain were compared. Images of treated brains were on average $27 \pm 5 \%$ less bright than control images.

In cryostat sections of the retina, the retinal ganglion cell (RGC) fiber layer, the inner and outer plexiform layers, and the optic nerve head were brightly labeled with the PY20 antibody at stage 39 (Fig. $5 C$ ). Cclls in the ciliary margins of the retina, which includes the proliferative zone, showed little immunoreactivity. To characterize the pattern of tyrosine phosphorylation in retinal neurites and their growth cones, dissociated retinae cultured on laminin for 8-10 hr were stained with the PY20 antibody. The cell bodies, axons, and growth cones of control retinal cells had punctate labeling, with bright spots frequently extending to the lamellar edges of the growth cones and along filopodia (Fig. 5D). Herbimycin A-treated retinal cells showed an overall reduction in punctate staining in the body of the growth cone and in filopodia (Fig. $6 E$ ). The persistence of some tyrosine phosphorylation may represent PTK activity not affected by the drugs and/or slow phosphatase-mediated turnover.

\section{Axon steering is not perturbed by PTK inhibitors}

Retinal axons normally follow a well defined route through the diencephalon (Holt, 1984; Harris, 1986). To investigate whether inhibition of PTKs interfered with the ability of axons to steer this route correctly, we assayed the trajectories of inhibitor-treated projections. At low doses of herbimycin A and lavendustin A ( 0.44 and $0.88 \mu \mathrm{M}$ herbimycin $\mathrm{A} ; 25 \mu \mathrm{M}$ RBI lavendustin $\mathrm{A}$ ), axons grew within the normal boundaries of the optic tract and, in many cases, fibers extended correctly to the optic tectum. In $\sim 50 \%$ of the cases at high concentrations of both drugs, an additional sparse projection consisting of 1-10 axons extended significantly further along the optic tract than a majority of the projection, enabling an assessment of their trajectories. An example is shown in Figure $1 E$ in which a dense bundle of optic fibers crosses the chiasm and abruptly narrows into a sparse projection in the ventral optic tract. In 3 of 108 samples treated with either 1.3 or $1.8 \mu \mathrm{M}$ herbimycin
A, or 75 or $100 \mu \mathrm{M}$ lavendustin A-the highest drug concentrations-one or two fibers reached as far as the optic tectum (Fig. $1 F$ ). For all concentrations of drugs used, no fibers were found to deviate significantly from the normal pathway. This was supported by a computer-aided analysis of superimposed projections. A composite control brain and projection image was generated by aligning and overlaying computer images of 30 control specimens from the herbimycin A experiments. The resulting image is shown in Figure $6 A$, in which the darker regions of the projection indicate areas of greater overlap between specimens. A similar composite was made of 23 specimens treated with $1.3 \mu \mathrm{M}$ herbimycin A. This concentration was chosen to maximize the number of sparse axons that elongated beyond the ventral optic tract. When an outline of the control composite projection was superimposed on the experimental composite image, the trajectories of all inhibitor-treated axons were seen to fall within the normal boundaries of the optic tract (Fig. 6B). This shows that retinal axon steering was not sensitive to the reduced levels of PTK activity achieved with herbimycin A treatment but leaves open the possibility that more specific or efficient $\mathrm{P}^{\prime} \mathrm{I}^{\prime} \mathrm{K}$ inhibition might impair this process.

\section{PTK inhibitors reduce neurite extension in vitro}

Although the in vivo approach we have used provides a valuable way to challenge axons in their native environment, it has the limitation that the responses seen could be attributable to effects on the neuroepithelial substrate rather than directly on the retinal axons. To address this point, we performed a parallel series of experiments in vitro. Dissociated eye primordia were cultured on laminin substrates in the presence or absence of PTK inhibitors, and neurite outgrowth was measured. Treated cultures appeared healthy, and no qualitative difference in the attachment of cells to laminin was observed. Neurite lengths measured after $10 \mathrm{hr}$ in culture displayed a dose-dependent decrease compared with controls (a summary of neurite lengths obtained in four experiments 

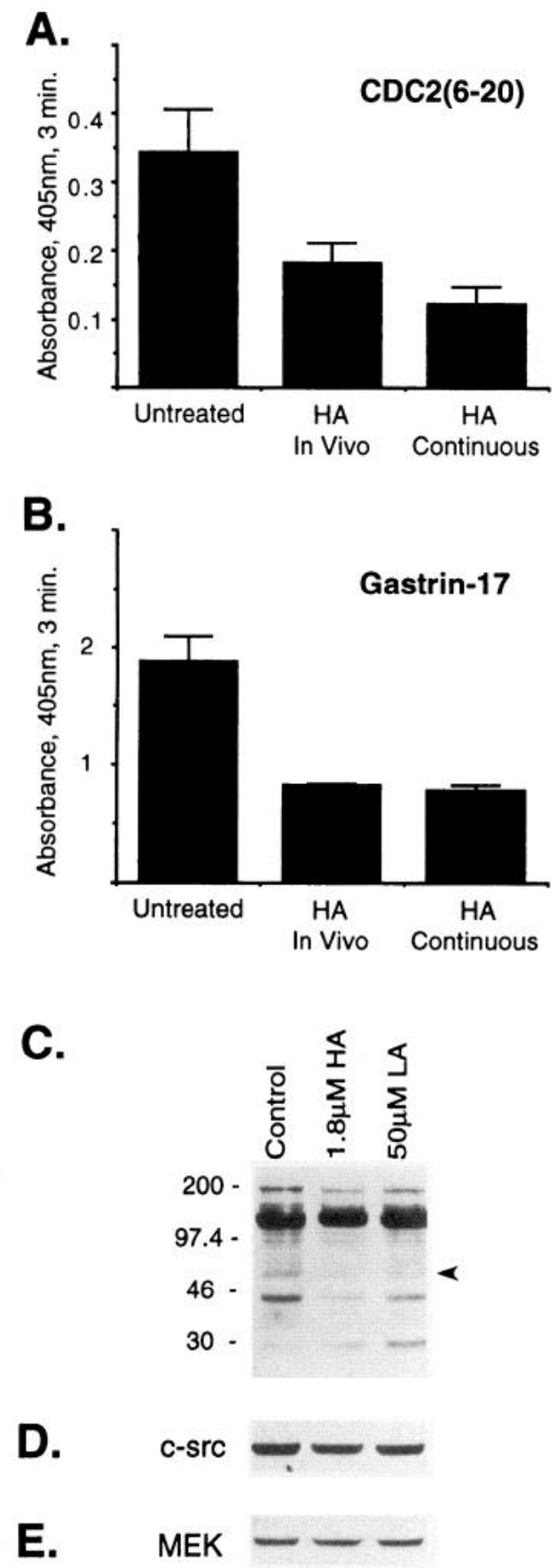

Figure 4. In vitro tyrosine kinase assay and Western blot analysis of control and treated brain homogenates. $A, B$, An in vitro tyrosine kinase assay using the cdc 2 and gastrin-17 peptides as substrates was performed on brain homogenates from embryos treated with herbimycin $\mathrm{A}(H A)$ for 4-5 hr. The phosphorylated peptides were analyzed with an ELISA assay. The absorbance values at $405 \mathrm{~nm}$ from one representative experiment are shown that demonstrate the PTK inhibitor-sensitive decrease in phosphorylation seen for both peptides. The consensus sequence for phosphorylation on the $\mathrm{cdc} 2$ peptide is specific for the $\operatorname{src}$ family PTKs, and the absorbance values for the cdc2 peptide $(A)$ are $\sim 20 \%$ of those of the gastrin-17 peptide $(B)$, which is phosphorylated by a variety of PTKs. Lanes marked $H A$ In Vivo refer to brains that were exposed to the drug during the bath incubation only. Lanes designated $H A$ Continuous are the results from samples exposed to herbimycin A during the bath and in the in vitro kinase assay. $C$, Anti-phosphotyrosine (anti-PY) blot of homogenates from exposed control brains (lane 1 ), brains treated with $1.8 \mu \mathrm{M}$ herbimycin A (lane 2), and $50 \mu \mathrm{M}$ RBI lavendustin A showing the relative changes in phosphorylation levels after inhibitor treatment. Each lane was loaded with $75 \mu \mathrm{g}$ of protein. The arrowhead indicates a $60 \mathrm{kDa}$ band for which phosphotyrosine staining decreases with PTK inhibitor exposure. $D$, The same blot as in $C$ probed with an antibody against with herbimycin $\mathrm{A}$ is shown in Fig. 7A). Neurite outgrowth in culture was found to be sensitive to as little as $0.055 \mu \mathrm{M}$ herbimycin $\mathrm{A}$ and, at the maximum dose (1.8 $\mu \mathrm{m}$ herbimycin $\mathrm{A})$, neurite lengths were $70-80 \%$ shorter than controls. Neurites in cultures treated with lavendustin A were also found to be shorter than control neurites in a concentration-dependent manner, with a $65-75 \%$ reduction in length at the maximum doses used (data not shown). In addition, the effects on neurite lengths with both drugs were found to be reversible (Fig. $7 A$ for herbimycin $\mathrm{A}$; data not shown for lavendustin A). Our finding of $70-80 \%$ reduction in outgrowth in vitro correlates with the $80 \%$ reduction in projection length in vivo and supports the possibility that the drugs directly inhibit axon growth in the embryo.

\section{Inhibitor treatment causes growth cone enlargement}

The growth cones of cultured retinal neurons were examined to find out whether PTK inhibition causes morphological changes. In both control and PTK inhibitor-treated cultures, neurites had growth cones with filopodia and lamellipodia. At $1.8 \mu \mathrm{M}$ herbimycin A, growth cones were significantly larger than normal (Table 1, Fig. 7B,C). The enlargement occurred in both width and length dimensions but was most significant along the length, giving rise to growth cones that were $\sim 50 \%$ longer than normal (Fig. 7C). A similar increase in size was also observed in cultures treated with $100 \mu \mathrm{M}$ Gibco lavendustin A (data not shown). The average number of filopodia did not differ significantly between control and treated growth cones. Thus, diminished PTK activity causes an expansion in growth cone size on a laminin substrate.

\section{PTK Inhibitors elicit opposite response in chick ciliary ganglion neurons}

Bixby and Jhabvala (1992) found an increase in neurite length and in the number of neurons sprouting neurites after the PTK inhibitors genistein and lavendustin A were applied to cultures of chick ciliary ganglion cells. Because our experiments showed a decrease in neurite length, as a positive control we cultured E8 dissociated chick ciliary ganglion cells in the presence of genistein and lavendustin A. These neurons showed increases in both the number and the length of neurites extended, a potentiation effect similar to that reported by Bixby and Jhabvala (1992) (Table 2). Furthermore, herbimycin $\mathrm{A}$, which was not previously used on these neurons, gave the greatest potentiation.

\section{DISCUSSION}

We tested the role of PTK activity in growing retinal neurons in two complementary assay systems: the native environment of the developing optic tract, and in vitro on laminin. Our main finding is that retinal axon extension is inhibited in both experimental systems when PTK activity is reduced by treatment with herbimycin A and lavendustin A. This indicates that inhibitorsensitive PTKs normally play a role in promoting the extension of retinal axons through the optic pathway and on laminin. We also show that inhibitor-treated growth cones are significantly

the $60 \mathrm{kDa}$ PTK $c$-src. Lanes 1 and 3 appear to contain equivalent amounts of protein, whereas the labeling of the band in lane 2 is slightly less intense, consistent with previous observations that herbimycin A treatment can cause some degradation of pp60 ${ }^{n-s r c}$ (Uehara et al., 1989; Garcia et al., 1991). $E$, Same blot as in $C$, stained with a polyclonal antibody against the dual-specificity kinases MEK1 and -2 to confirm that equal amounts of protein appear to be present with no indication of protein degradation in the herbimycin A-treated lane. 

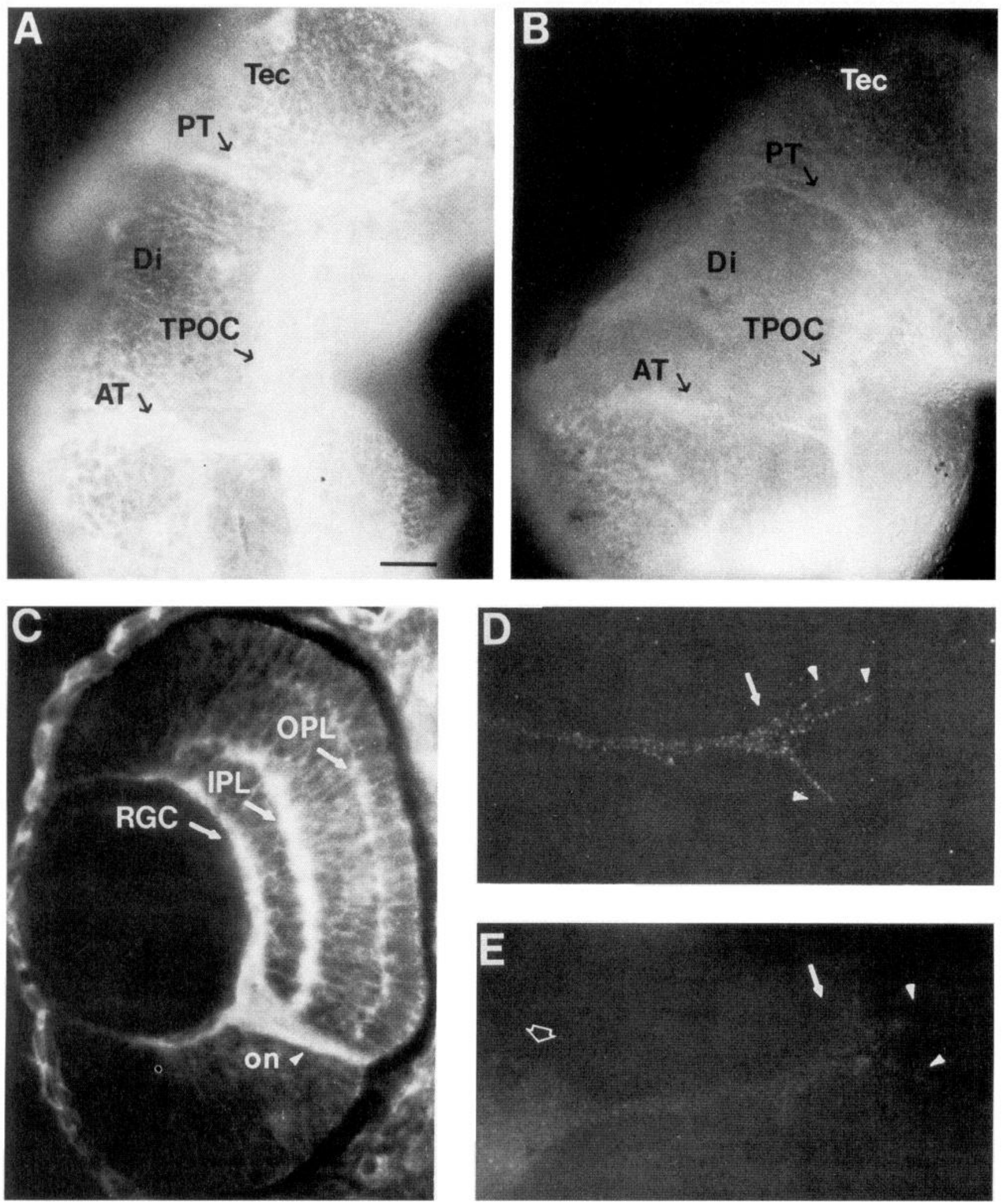

Figure 5. Levels of phosphotyrosine immunostaining diminish with herbimycin A. A, Stage 35/36 exposed control brain showing intense immunofluorescence in the early axonal tracts when labeled with the PY20 antibody and around the edges of neuroepithelial endfeet. $B$, Stage $35 / 36$ brain treated with $1.8 \mu \mathrm{M}$ herbimycin A showing an overall reduction in staining intensity compared with $A$. (The exposure time was the same as in $A$.) $C$, Transverse section through a control stage 39 retina showing bright immunoreactivity in the $R G C$ fiber layer, the inner and outer plexiform layers (IPL, $O P L$ ), and the optic nerve head (on). D, Tip of untreated retinal neurite in culture exhibits bright punctate staining along the axon, in the growth cone (arrow) and along filopodia (arrowheads). The cell body is outside the field of view. E, Growth cone treated with $1.8 \mu \mathrm{M}$ herbimycin A in culture. Some staining is present but severely diminished compared with $D$ and is concentrated in the center of the growth cone (arrow), with decreased immunoreactivity at the leading edges and filopodia (arrowheads). The neurite is short, and the cell body is in the field of view (open arrow). The exposure times for $D$ and $E$ were the same. Scale bar (shown in $A$ ): $50 \mu \mathrm{m}$ in $A, B ; 25 \mu \mathrm{m}$ in $C ; 10 \mu \mathrm{m}$ in $D, E$. AT, Anterior tract; TPOC, tract of the postoptic commissure; PT, posterior tract; $D i$, diencephalon; $T e c$, tectum. Dorsal is up in $A-C$; anterior is to the left in $A$ and $B$. 

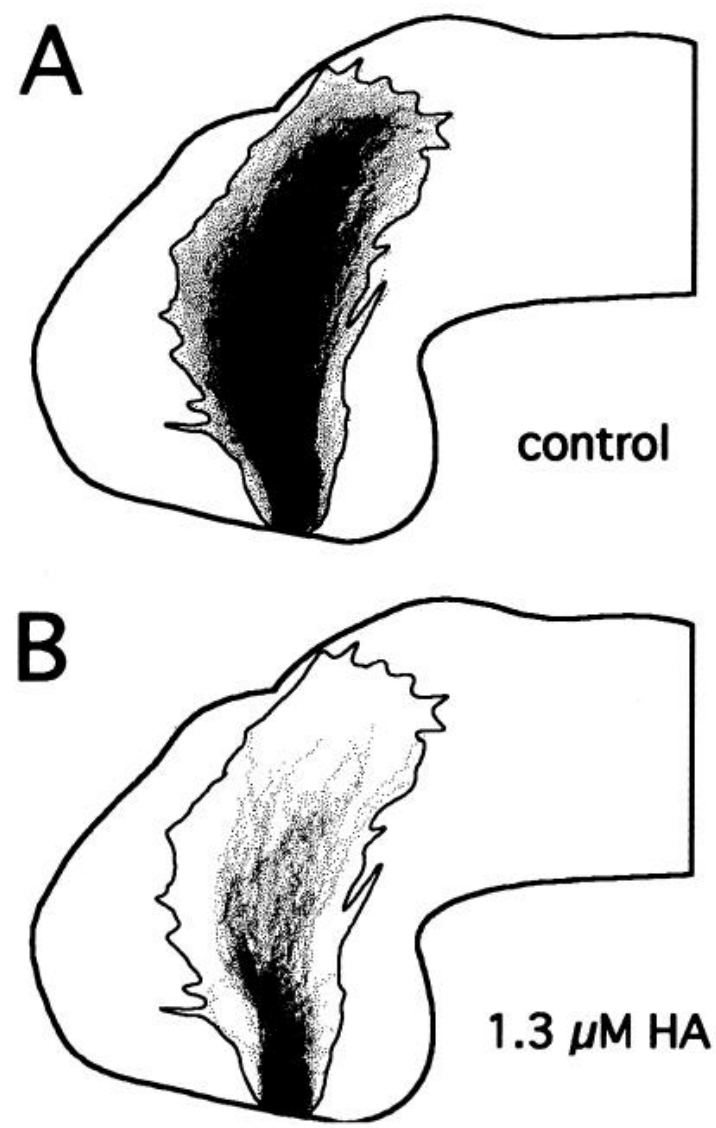

Figure 6. Axon trajectories unaltered by herbimycin A. A, Superimposed profiles of 30 retinal projections from stage 39 exposed control specimens. Darker areas indicate regions of greater overlap. B. Composite image of 23 retinal projections from stage 39 embryos exposed to $1.3 \mu \mathrm{M}$ herbimycin A beginning at stage 32 . All fibers are within the normal boundary of the optic tract defined by the control projection (solid outline).

larger than normal on laminin, which suggests that PTK activity modulates the size of growth cones in response to substrate interactions. Finally, an interesting aspect of this study is the demonstration that the same PTK inhibitors elicit opposite responses in two different classes of neurons, Xenopus retinal neurons and chick ciliary ganglion neurons. The distinct responses to PTK inhibition may reflect cell-type differences in the activity or expression of PTKs (and/or phosphatases) that are stimulated by laminin.

A potential problem with using pharmacological inhibitors is that they typically affect a range of PTKs (Uehara et al., 1986, 1989; Onoda et al., 1989, 1990; Fukazawa et al., 1990, 1991; Garcia et al., 1991; Uehara and Fukazawa, 1991; Hamaguchi et al., 1993a,b). We chose herbimycin A and lavendustin A because they effectively inhibit a similar group of receptor and cytoplasmic PTKs, such as the epidermal growth factor receptor (EGFR) and pp60 $60^{c-s r c}$, with only weak effects on the enzymatic activity of protein kinases A or C at high concentrations (Onoda et al., 1989; Garcia et al., 1991; O’Dell et al., 1991; Uehara and Fukazawa, 1991; Li et al., 1993). They are not structurally related, and they inhibit PTKs by different mechanisms. Lavendustin A competes for the ATP-binding site (Onoda et al., 1989), whereas herbimycin A hinders PTK activity by covalently binding its PTK target (Uehara et al., 1989; Fukazawa et al., 1990, 1994; Garcia et al., 1991). The fact that both of these inhibitors gave similar results in
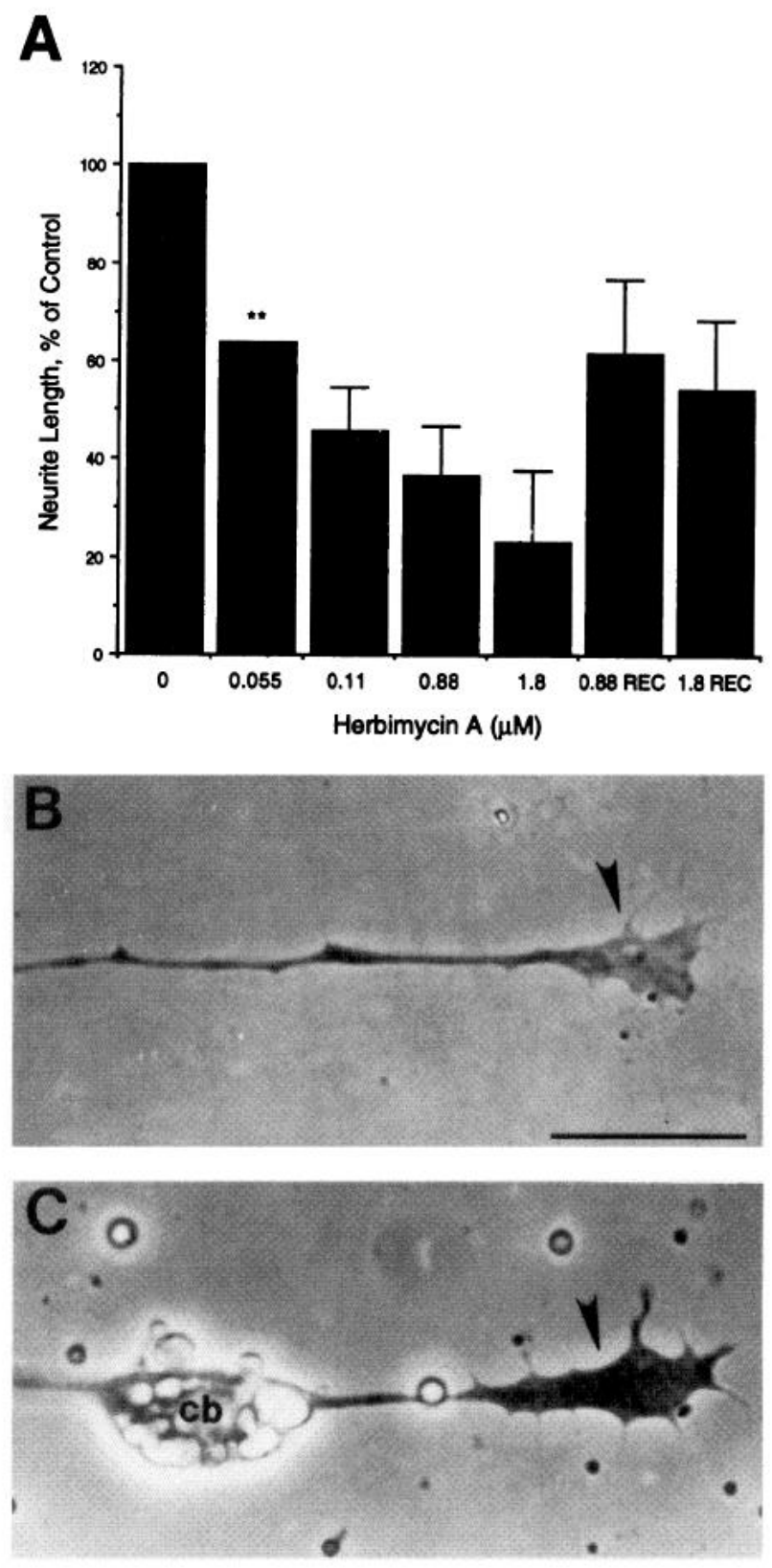

Figure 7. Herbimycin A inhibits neurite outgrowth and causes enlargement of growth cones in vitro. $A$, Neurites of dissociated retinal neurons treated for $10 \mathrm{hr}$ with herbimycin A were measured in four separate experiments, and the data were combined and expressed as a percentage of control neurite outgrowth. The average control neurite length for all four experiments was $230 \pm 58 \mu \mathrm{m}$, and 100-300 neurites were analyzed for each concentration. Treated neurites are significantly shorter in a dose-dependent manner. REC (recovery) designates the cultures in which the drug-containing medium was changed to control medium after $5 \mathrm{hr}$ of exposure. ${ }^{* *}$ This concentration was analyzed in only a single experiment, in which 70 neurites were measured. $B, C$, Phase-contrast photomicrographs of retinal neurons cultured for $10 \mathrm{hr}$ with or without herbimycin A and stained with toluidine blue to enhance the contrast. $B$, Control growth cone (arrowhead) exhibiting typical size and morphology. The neurite is long, and the cell body is out of the field of view. $C$, Herbimycin A (1.8 $\mu \mathrm{M})$-treated neuron has short neurite extending from cell body $(c b)$ and is tipped with an enlarged growth cone (arrowhead). Scale bar, $25 \mu \mathrm{m}$.

our in vivo and in vitro studies strongly suggests that the underlying cause of impaired axon extension was the direct inhibition of PTK activity.

Previous studies have established that PTK activity is de- 


\begin{tabular}{|c|c|c|c|c|}
\hline Experiment & $n$ & $\begin{array}{l}\text { \# } \\
\text { Filopodia }\end{array}$ & $\begin{array}{l}\text { Average } \\
\text { width }(\mu \mathrm{m})\end{array}$ & $\begin{array}{l}\text { Average } \\
\text { length }(\mu \mathrm{m})\end{array}$ \\
\hline \multicolumn{5}{|l|}{ Experiment 1} \\
\hline Control & 35 & $5.1 \pm 0.6$ & $3.1 \pm 0.2$ & $19.4 \pm 1.8$ \\
\hline $0.88 \mu \mathrm{M}$ HA & 33 & $4.8 \pm 0.6$ & $4.3 \pm 0.7$ & $20.2 \pm 1.9$ \\
\hline \multicolumn{5}{|l|}{ Experiment 2} \\
\hline Control & 31 & $3.2 \pm 0.2$ & $5.0 \pm 0.4$ & $22.9 \pm 2.2$ \\
\hline $0.88 \mu \mathrm{M}$ HA & 30 & $3.5 \pm 0.5$ & $6.0 \pm 0.7$ & $29.0 \pm 2.3^{*}$ \\
\hline \multicolumn{5}{|l|}{ Experiment 3} \\
\hline Control & 31 & $2.8 \pm 0.3$ & $3.1 \pm 0.2$ & $10.9 \pm 1.2$ \\
\hline $1.8 \mu \mathrm{M} \mathrm{HA}$ & 30 & $2.8 \pm 0.4$ & $4.1 \pm 0.4^{*}$ & $16.2 \pm 1.3^{*}$ \\
\hline \multicolumn{5}{|l|}{ Experiment 4} \\
\hline Cuntrol & 32 & $2.3 \pm 0.4$ & $2.4 \pm 0.2$ & $11.1 \pm 1.0$ \\
\hline $1.8 \mu \mathrm{M} \mathrm{HA}$ & 33 & $2.3 \pm 0.3$ & $3.7 \pm 0.3^{*}$ & $15.9 \pm 1.3^{*}$ \\
\hline
\end{tabular}

${ }^{*} p \leq 0.03$, one-tailed $t$ test.

creased in cultured cells treated with the same drugs (Uehara et al., 1986, 1989; Yamaki et al., 1989; Fukazawa et al., 1991; Garcia et al., 1991; Li et al., 1993). The present study documents with three independent lines of evidence that PTK activity is significantly inhibited in brains in vivo. First, inhibitor-treated brains show diminished levels of phosphotyrosine immunostaining compared with exposed control brains. Second, at least eight proteins observed in Western blots of inhibitor-treated brain homogenates exhibit reduced levels of tyrosine phosphorylation. Although anti-phosphotyrosine antibody labeling is an indirect method of observing PTK activity, because the phosphorylation state of a protein depends on both PTK and phosphatase activity, the immunofluorescence and Western blot data are consistent with a decrease in PTK activity. Third, PTK activity directly assessed in crude homogenates from brains treated with herbimycin $\mathrm{A}$ is reduced by $50-60 \%$. None of the treatments or assays we performed resulted in the complete loss of PTK activity, indicating that some brain PTKs were not sensitive to the drugs (Onoda et al., 1989; Li et al., 1993; Smyth et al., 1993). Alternatively, the inhibitors may not have reached cells deep in the neuroepithelium.

Although the exposed brain preparation provides an accessible in vivo system, it has the limitation that drugs have access not only to the retinal axons but to their neuroepithelial substrate as well. This raises the question of whether the inhibition of axon out-

Table 2. Dissociated chick ciliary ganglia treated with PTK inhibitors

\begin{tabular}{lll} 
Drug & $\begin{array}{l}\text { Neurons with } \\
\text { neurites (\%) }\end{array}$ & $\begin{array}{l}\text { Average total } \\
\text { neurite length (\%) }\end{array}$ \\
\hline Control & 100 & 100 \\
$100 \mu \mathrm{M}$ genistein & 139 & 127 \\
$1 \mu \mathrm{M}$ lavendustin A & 118 & 94 \\
$10 \mu \mathrm{M}$ lavendustin A & 128 & 101 \\
$0.22 \mu \mathrm{M}$ herbimycin A & 129 & 120 \\
$0.44 \mu \mathrm{M}$ herbimycin A & 151 & 145
\end{tabular}

Dissociated chick ciliary ganglia were plated (in duplicate) in control medium or medium containing a PTK inhibitor and were incubated for $4-6 \mathrm{hr}$. Between 300 and 500 cells per culture were counted to determine the percentage of neurons with neurites, and the total neurite length per neuron was measured for more than 30 neurons in each culture. growth seen in vivo resulted from effects on the substrate tissue or the axons. Our studies showed that neurite outgrowth in vitro is reduced to a similar degree as that in vivo, which favors the idea that the inhibitors exert their effects directly on PTKs in the axons. However, it is still possible that some of the in vivo inhibition arises indirectly from effects on, for example, growth promoting molecules in the substrate.

At the higher doses of herbimycin A used (1.3 and $1.8 \mu \mathrm{M})$, we often found a small group of fibers (1-10) that extended further into the optic tract than the stalled majority. These axons followed the normal pathway without exhibiting pathfinding errors, leading to the conclusion that these PTK inhibitors do not affect the steering decisions of growing retinal axons at concentrations that effectively inhibit axon extension. This observation does not eliminate the possibility that PTKs sensitive to the inhibitors arc involved in axon navigation because guidance deficiencies may have been masked by the impairment of elongation. It is not clear why a few axons were able to extend a significant distance into the optic tract whereas most did not. One possibility is that the amount of PTK inhibition varied between individual fibers because of either differences in drug accessibility or intrinsic differences in PTK composition or activity. Another possibility is that some fibers may have been more efficient at responding to cues in the neuroepithelium that do not require mediation by PTK activity, such as a $\mathrm{Ca}^{2+}$ - or a $\mathrm{Ca}^{2+}$-calmodulin signaling mechanism (Bixby et al., 1994; VanBerkum and Goodman, 1995).

Many studies have documented that growth cones undergo morphological changes when they encounter different substrates in vitro (Letourncau, 1975; Argiro et al., 1984; Lemmon et al., 1992; Burden-Gulley et al., 1995; Fan and Raper, 1995) and when they enter new microterrains in vivo (Bovolenta and Mason, 1987; Holt, 1989; Godement et al., 1994). Alterations in growth cone shape have been shown to correlate with different aspects of growth cone behavior such as adhesiveness to the substrate, rate of advancement, and directional orientation; however, the molecular basis underlying these behaviors is poorly understood. The enlargement of retinal growth cones that we observed on laminin with PTK inhibition suggests that lyrosine phosphorylation may regulate growth cone shape and, therefore, possibly behavior. In support of this idea, the PTK FAK, which is present in Xenopus retinal growth cones (Worley and Holt, 1995), recently has been found to play an important role in regulating the shape and migration of mesodermal and fibroblast-like cells cultured on laminin (llic et al., 1995).

We were able to show that src family PTK activity was reduced by both drugs in exposed brains using an in vitro tyrosine kinase assay. pp60 $60^{\text {c. }}$ is a potentially interesting target because it is present in RGCs and growth cones (Sorge et al., 1984; Maness et al., 1990; Sugrue et al., 1990) and may mediate signals from molecules that are important for neurite extension, such as integrin (Hirst et al., 1986; Kornberg et al., 1991; Matsuyoshi et al., 1992; Behrens et al., 1993; Hamaguchi et al., 1993a,b; Ignelzi et al., 1994; Xing et al., 1994). Xenopus retinal axon extension is severely inhibited in vivo when integrin function is perturbed by the transgenic expression of chimeric $\beta 1$ integrins (Lilienbaum et al., 1995), and here we observed that PTK inhibition impairs neurite outgrowth on laminin, an extracellular matrix ligand for certain $\beta 1$ integrin heterodimers. However, neurite extension from cerebellar neurons from transgenic mice null for src or fyn is normal on laminin substrates (Beggs et al., 1994; Ignelzi et al., 1994). The lack of an effect may reflect functional redundancy between $s r c$ and fyn, 
which have been reported to phosphorylate overlapping substrates (Sartor and Robbins, 1993; Thomas et al., 1995). Transgenic mice doubly mutant for src and fyn can survive until birth (Stein et al., 1994), and studies of embryonic neurite outgrowth in these animals should address this issue further.

Some of the intracellular substrates phosphorylated by activated pp $60^{c-s r c}$ are associated with the actin cytoskeleton, the structure and formation of which are also necessary for the extension of neurites (Sefton and Hunter, 1981; Pasquale et al., 1986; Matten et al., 1990; Wu et al., 1991; Atashi et al., 1992; Reynolds et al., 1992; Wong et al., 1992; Wu and Parsons, 1993). When the function of one such molecule, vinculin, was blocked in NGF-primed $\mathrm{PCl} 2$ cells with antisense mRNA, neurites were shorter and growth cones larger in size than controls on a laminin substrate (Varnum-Finney and Reichardt, 1994). This phenotype is very similar to the one reported here when cultured neurites were exposed to herbimycin A and lavendustin A. Therefore, the effects of PTK inhibition on the developing retinal projection in Xenopus may be attributable in part to the inhibition of $p p 60^{c-s r c}$ signaling from cell-surface molecules to cytoskeletal substrates.

Many extracellular and intracellular molecules have been found to be important for promoting neurite elongation in culture. To determine the functional role that each plays in signaling the extension of axons toward their targets, these molecules and their activities need to be tested in vivo. Our observations of the effects of PTK inhibition on optic axon growth in vivo provide evidence that the regulation of tyrosine phosphorylation is involved in retinal axon extension, and we suggest that $\mathrm{pp} 60^{c-s r}$ may be one of the PTKs active in this signaling cascade.

\section{REFERENCES}

Argiro V, Bunge M, Johnson MI (1984) Correlation between growth form and movement and their dependence on neuronal age. J Neurosci 4:3051-3062.

Atashi JR, Klinz SG, Ingraham CA, Matten WT, Schachner M, Maness PF (1992) Neural cell adhesion molecules modulate tyrosine phosphorylation of tubulin in nerve growth cone membranes. Neuron 8:831-842.

Baldwin GS, Knesel J, Monkton JM (1983) Phosphorylation of gastrin-17 by epidermal growth factor-stimulated tyrosine kinase. Nature 301:435-437.

Bare DJ, Lauder JM, Wilkie MB, Maness PF (1993) p59 ${ }^{\mathrm{fyn}}$ in rat brain is localized in developing axonal tracts and subpopulations of adult neurons and glia. Oncogene 8:1429-1436.

Beggs HE, Soriano P, Maness PF (1994) NCAM-dependent neurite outgrowth is inhibited in neurons from Fyn-minus mice. J Cell Biol 127:825-833.

Behrens J, Vakaet L, Friis R, Winterhager E, Van RF, Mareel MM, Birchmeier W (1993) Loss of epithelial differentiation and gain of invasiveness correlates with tyrosine phosphorylation of the E-cadherin/ beta-catenin complex in cells transformed with a temperature-sensitive v-SRC gene. J Cell Biol 120:757-766.

Biscardi JS, Shores CG, Maness PF (1991) Elevated protein tyrosine phosphorylation in the optic tract of the chick embryo. Curr Eye Res 10:1121-1128.

Bixby JL, Harris WA (1991) Molecular mechanisms of axon growth and guidance. Annu Rev Cell Biol 7:117-159.

Bixby JL, Jhabvala P (1992) Inhibition of tyrosine phosphorylation potentiates substrate-induced neurite growth. J Neurobiol 23:468-480.

Bixby JL, Jhabvala P (1993) Tyrosine phosphorylation in early embryonic: growth cones. J Neurosci 13:3421-3432.

Bixby JL, Grunwald GB, Bookman RJ (1994) $\mathrm{Ca}^{2+}$ influx and neurite growth in response to purified $\mathrm{N}$-cadherin and laminin. J Cell Biol 127:1461-1475.

Bolaventa P, Mason C (1987) Growth cone morphology varies with position in the developing mouse visual pathway from retina to first targets. J Neurosci 7:1447-1460.
Burden-Gulley SM, Payne HR, Lemmon V (1995) Growth cones are actively influenced by substrate-bound adhesion molecules. J Neurosci $15: 4370-4381$.

Cheng HC, Nishio H, Hatase O, Ralph S, Wang JH (1992) A synthetic peptide derived from $\mathrm{p} 34 \mathrm{cdc} 2$ is a specific and efficient substrate of src-family tyrosine kinases. J Biol Chem 267:9248-9256.

Cheng Hwai-Jong Nakamoto M, Bergemann AD, Flanagan JG (1995) Complementary gradients in expression and binding of ELF-1 and Mek4 in development of the topographic retinotectal projection map. Cell 82:371-382.

Chien CB, Harris WA (1994) Axonal guidance from retina to tectum in embryonic Xenopus. Curr Top Dev Biol 29:135-169.

Chien CB, Rosenthal DE, Harris WA, Holt CE (1993) Navigational errors made by growth cones without filopodia in the embryonic Xenopus brain. Neuron 11:237-251.

Cobb BS, Schaller MD, Leu TH, Parsons JT (1994) Stable association of pp $60^{\text {src }}$ and $p p 59^{\text {fyn }}$ with the focal adhesion-associated protein tyrosine kinase, pp125FAK. Mol Cell Biol 14:147-155.

Cohen CS, Fraser SE (1994) BDNF in the development of the visual system of Xenopus. Neuron 12:747-761.

Cornel E, Holt C (1992) Precocious pathfinding: retinal axons can navigate in an axonless brain. Neuron 9:1001-1011.

Dodd J, Jcsscll TM (1988) Axon guidance and the patterning of neuronal projections in vertebrates. Science 242:692-699.

Durkin WJ, Ghanta VK, Balch CM, Davis DW, Hiramoto RN (1979) A methodological approach to the prediction of anticancer drug effect in humans. Cancer Res 39:402-407.

Easter SS, Taylor JSH (1989) The development of the Xenopus retinofugal pathway: optic fibers join a pre-existing tract. Development 7:553-573.

Escandon E, Soppet D, Rosenthal $\Lambda$, Mendoza-Ramirez JL, Szonyi E, Burton LE, Henderson CE, Parada LF, Nikolics K (1994) Regulation of neurotrophin receptor expression during embryonic and postnatal development. J Neurosci 14:2054-2068.

Fan J, Raper JA (1995) Localized collapsing cues can steer growth cones without inducing their full collapse. Neuron 14:263-274.

Fox JE, Lipfert L, Clark EA, Reynolds CC, Austin CD, Brugge JS (1993) On the role of the platelet membrane skeleton in mediating signal transduction. Association of GP IIb-IIIa, pp60 $60^{\mathrm{c}-\mathrm{src}}: \mathrm{pp} 62^{\mathrm{c}-\mathrm{yes}}$, and the $\mathrm{p} 21^{\text {ras }}$ GTPase-activating protein with the membrane skeleton. J Biol Chem 268:25973-25984.

Fukazawa H, Mizuno S, Uehara Y (1990) Effects of herbimycin A and various $\mathrm{SH}$-reagents on $\mathrm{p} 60^{v-s r c}$ kinase activity in vitro. Biochem Biophys Res Commun 173:276-282.

Fukazawa H, Li P-M, Yamamoto C, Murakami Y, Mizuno S, Uehara Y (1991) Specific inhibition of cytoplasmic protein tyrosine kinases by herbimycin A in vitro. Biochem Pharmacol 42:1661-1671.

Fukazawa H, Uehara Y, Murakami Y, Mizuno S, Hamada M, Takeuchi T (1994) Labeling of v-src and bcr-abl tyrosine kinases with $\left({ }^{14} \mathrm{C}\right)$ herbimycin $A$ and its use in the elucidation of the kinase inactivation mechanism. FEBS Lett 340:155-158.

Garcia R, Parikh NU, Saya H, Gallick GE (1991) Effect of herbimycin A on growth and pp $60^{\text {c-src }}$ activity in human colon tumor cell lines. Oncogene 6:1983-1989.

Godement P, Wang L, Mason C (1994) Retinal axon divergence in the optic chiasm: dynamics of growth cone behavior at the midline. J Neurosci 14:7024-7039.

Guan JL, Shalloway D (1992) Regulation of focal adhesion-associated protein tyrosine kinase by both cellular adhesion and oncogenic transformation. Nature 358:690-692.

Guan JL, Trevithick JE, Hynes RO (1991) Fibronectin/integrin interaction induces tyrosine phosphorylation of a $120 \mathrm{kDa}$ protein. Cell Regul Pept 2:951-964.

Hamaguchi M, Matsuyoshi N, Ohnishi Y, Gotoh B, Takeichi M, Nagai Y (1993a) $\mathrm{p} 60^{v-s r c}$ causes tyrosine phosphorylation and inactivation of the $\mathrm{N}$-cadherin-catenin cell adhesion system. EMBO J 12:307-314.

Hamaguchi M, Xiao H, Uehara Y, Ohnishi Y, Nagai Y (1993b) Herbimycin $A$ inhibits the association of p $60^{\nu-s r c}$ with the cytoskeletal structure and with phosphatidylinositol $3^{\prime}$ kinase. Oncogene 8:559-564.

Harris WA (1986) Homing behaviour of axons in the embryonic vertebrate brain. Nature 320:218-221.

Harris WA, Messersmith SL (1992) Two cellular inductions involved in photoreceptor determination in the Xenopus retina. Neuron 9:357-372. 
Harris WA, Holt CE, Smith TA, Gallenson N (1985) Growth cones of developing retinal cells in vivo, on culture surfaces, and in collagen matrices. J Neurosci Res 13:101-122.

Hashimoto S (1988) K-252a, a potent protein kinase inhibitor, blocks nerve growth factor-induced neurite outgrowth and changes in the phosphorylation of proteins in PC12h cells. J Cell Biol 107:1531-1539.

Hirst R, Horwilz A, Buck C, Ruhrschneider L (1986) Phosphorylation of the fibronectin receptor complex in cells transformed by oncogenes that encode tyrosine kinases. Proc Natl Acad Sci USA 83:6470-6474.

Holt CE (1984) Does timing of axon outgrowth influence initial retinotectal topography in Xenopus? J Neurosci 4:1130-1152.

Holt CE (1989) A single-cell analysis of early retinal ganglion cell differentiation in Xenopus: from soma to axon tip. $\mathbf{J}$ Neurosci 9:3123-3145.

Holt CE, Harris WA (1993) Position, guidance, and mapping in the developing visual system. J Neurobiol 21:1100-1422.

Huang MM, Lipfert L, Cunningham M, Brugge JS, Ginsberg MH, Shattil SJ (1993) Adhesive ligand binding to integrin alpha IIb beta 3 stimulates tyrosine phosphorylation of novel protein substrates before phosphorylation of pp125FAK. J Cell Biol 122:473-483.

Ignelzi MJ, Miller DR, Soriano P, Maness PF (1994) Impaired neurite outgrowth of src-minus cerebellar neurons on the cell adhesion molecule L1. Neuron 12:873-884.

Ilic D, Furuta Y, Kanazawa S, Takeda N, Sobue K, Nakatsuji N, Nomura S, Fujimoto J, Okada M, Yamamoto T, Alzawa S (1995) Reduced cell motility and enhanced focal adhesion contact formation in cells from FAK-deficient mice. Nature 377:539-544.

Ingraham CA, Cooke MP, Chuang YN, Perlmutter RM, Maness PF (1992) Cell type and developmental regulation of the fyn protooncogene in neural retina. Oncogene 7:95-100.

Jelsma TN, Friedman HH, Berkelaar M, Bray GM, Aguayo AJ (1993) Different forms of the neurotrophin receptor trkB mRNA prcdominate in rat retina and optic nerve. J Neurobiol 24:1207-1214.

Knusel B, Hefti F (1992) K-252 compounds: modulators of neurotrophin signal transduction. J Neurochem 59:1987-1996.

Knusel B, Kaplan DR, Winslow JW, Rosenthal A, Burton LE, Beck KD, Rabin S, Nikolics K, Hefti F (1992) K-252b selectively potentiates ccllular actions and trk tyrosine phosphorylation mediated by neurotrophin-3. J Neurochem 59:715-722.

Kornberg LJ, Earp HS, Turner CE, Prockop C, Juliano RL (1991) Signal transduction by integrins: increased protein tyrosine phosphorylation caused by clustering of beta 1 integrins. Proc Natl Acad Sci USA 88:8392-8396.

Laemmli UK (1970) Cleavage of structural proteins during the assembly of the head of bacteriophage T4. Nature 227:680-685.

Lemmon V, Burden S, Payne HR, Elmslie GJ, Hlavin ML (1992) Neurite growth on different substrates: permissive versus instructive influences and the role of adhesive strength. J Neurosci 12:818-826.

Letourneau PC (1975) Possible roles for cell-to-substratum adhesion in neuronal morphogenesis. Dev Biol 44:77-91.

Li P-M, Fukazawa H, Mizuno S, Uehara Y (1993) Evaluation of protein kinase inhibitors in an assay system containing multiple protein kinase activities. Anticancer Res 13:1957-1964.

Lilienbaum A, Reszka AA, Horwitz AF, Holt C (1995) Chimeric integrins expressed in retinal ganglion cells impair process outgrowth in vivo. Mol Cell Neurosci 6:139-152.

Lipfert L, Haimovich B, Schaller MD, Cobb BS, Parsons JT, Brugge JS (1992) Integrin-dependent phosphorylation and activation of the protein tyrosine kinase pp125FAK in platelets. J Cell Biol 119:905-912.

Maness PF, Shores CG, Ignelzi M (1990) Localization of the normal cellular src protein to the growth cone of differentiating neurons in brain and retina. Adv Exp Med Biol 265:117-125.

Matsuyoshi N, Hamaguchi M, Taniguchi S, Nagafuchi A, Tsukita S, Takeichi M (1992) Cadherin-mediated cell-cell adhesion is perturbed by v-src tyrosine phosphorylation in metastatic fibroblasts. J Cell Biol 118:703-714.

Matten WT, Aubry M, West J, Maness PF (1990) Tubulin is phosphorylated at tyrosine by pp $60^{c-s r c}$ in nerve growth cone membranes. $J$ Cell Biol 1959-1970.

McFarlane S, McNeill L, Holt C (1995) FGF signaling and target recognition in the developing Xenopus visual system. Neuron 15:1-20.

Miller DR, Lee GM, Maness PF (1993) Increased neurite outgrowth induced by inhibition of protein tyrosine kinase activity in $\mathrm{PC} 12$ pheochromocytoma cells. J Neurochem 60:2134-2144.

Nieuwkoop PD, Faber J (1967) The normal table of Xenopus laevis (Daudin). Amsterdam: North-Holland.
Nishi R, Berg DK (1981) Two components from eye tissue that differentially stimulate the growth and development of ciliary ganglion neurons in cell culture. $\mathrm{J}$ Neurosci 1:505-513.

O'Dell TJ, Kandel ER, Grant SGN (1991) Long-term potentiation in the hippocampus is blocked by tyrosine kinase inhibitors. Nature $353: 558-560$.

Onoda T, Iinuma $\mathrm{H}$, Sasaki $Y$, Hamada $M$, Isshiki $K$, Naganawa $H$, Takeuchi $\mathrm{T}$ (1989) Isolation of a novel tyrosine kinase inhibitor, lavendustin A, from Streptomyces griseolavendus. J Natural Products 52:1252-1257.

Onoda T, Isshiki K, Takeuchi T, Tatsuta K, Umezawa K (1990) Inhibition of tyrosine kinase and epidermal growth factor receptor internalization by lavendustin A methyl ester in cultured A431 cells. Drugs Exp Clin Res 16:249-53.

Pasquale EB, Maher PA, Singer SJ (1986) Talin is phosphorylated on tyrosine in chicken embryo fibroblasts transformed by Rous sarcoma virus. Proc Natl Acad Sci USA 83:5507-5511.

Pasquale EB, Connor RJ, Rocholl D, Schnurch H, Risau W (1994) Cek5, a tyrosine kinase of the Eph subclass, is activated during neural retina differentiation. Dev Biol 163:491-502.

Reynolds AB, Herbert L, Cleveland JL, Berg ST, Gaut JR (1992) p120, a novel substrate of protein tyrosine kinase receptors and of p60v-src, is related to cadherin-binding factors beta-catenin, plakoglobin and armadillo. Oncogene 7:2439-45.

Sajjadi FG, Pasquale EB (1993) Five novel avian Eph-related tyrosine kinases are differentially expressed. Oncogene 8:1807-1813.

Sartor O, Robbins KC (1993) Substratc spccificity for normal but not mutationally activated variants of src family kinases. J Biol Chem 268:21014-21020.

Schaller MD, Hildebrand JD, Shannon JD, fox JW, Vines RR, Parsons JT (1994) Autophosphorylation of the focal adhesion kinase, pp125FAK, directs SH2-dependent binding of pp60src. Mol Cell Biol 14:1680-1688.

Schlacpfer DD, Hanks SK, Hunter T, van der Geer P (1994) Integrinmediated signal transduction linked to Ras pathway by GRB2 binding to focal adhesion kinase. Nature 372:786-791.

Sefton BM, Hunter T (1981) Vinculin: a cytoskeletal target of the transforming protein of the Rous sarcoma virus. Cell 24:165-174.

Shattil SJ, Haimovich B, Cunningham M, Lipfert L, Parsons JT, Ginsberg $\mathrm{MH}$, Brugge JS (1994) Tyrosine phosphorylation of pp125FAK in platelets requires coordinated signaling through integrin and agonist receptors. J Biol Chem 269:14738-14745.

Shores CG, Maness PF (1989) Tyrosine phosphorylated proteins accumulate in the junctional regions of the developing chick neural retina. J Neurosci Res 24:59-66.

Smyth MS, Stefanova I, Hartmann F, Horak ID, Osherov N, Levitzki A, Burke Jr TR (1993) Non-amine based analogues of lavendustin A as protein-tyrosine kinase inhibitors. J Med Chem 36:3010-3014.

Surge LK, Levy BT, Maness PF (1984) pp60 $0^{c-s r}$ is developmentally regulated in the neural retina. Cell 36:249-257.

Soriano P, Montogomery C, Geske R, Bradley A (1991) Targeted disruption of the $c$-src proto-oncogene leads to osteopetrosis in mice. Cell 64:693-702.

Stein PL, Vogel H, Soriano P (1994) Combined deficiencies of Src, Fyn, and Yes tyrosine kinases in mutant mice. Genes Dev 8:1999-2007.

Sugrue MM, Brugge JS, Marshak DR, Greengard P, Gustafson EL (1990) Immunocytochemical localization of the neuron-specific form of the c-src gene product, pp60c-src(+), in rat brain. J Neurosci 10:2513-2527.

Takahashi JB, Hoshimaru M, Kikuchi H, Hatanaka M (1993) Developmental expression of trkB and low-affinity NGF receptor in the rat retina. Neurosci Lett 151:174-177.

Tcheng M, Fuhrmann G, Hartmann MP, Courtois Y, Jeanny JC (1994) Spatial and temporal expression patterns of FGF receptor genes type 1 and type 2 in the developing chick retina. Exp Eye Res 58:351-358.

Thomas SM, Soriano P, Imamoto A (1995) Specific and redundant roles of src and fyn in organizing the cytoskeleton. Nature 376:267-271.

Towbin H, Staehelin T, Gordon J (1979) Electrophoretic transfer of protcins from polyacrylamide gcls to nitroccllulose sheets: procedure and some applications. Proc Natl Acad Sci USA 76:4350-4354.

Uehara Y, Fukazawa H (1991) Use and selectivity of herbimycin A as inhibitor of protein-tyrosine kinases. Methods Enzymol 201:370-379.

Uehara Y, Hori M, Takeuchi T, Umezawa H (1986) Phenotypic change from transformed to normal induced by benzoquinoid ansamycins accompanies inactivation of $\mathrm{p} 60^{\mathrm{src}}$ in rat kidney cells infected with Rous sarcoma virus. Mol Cell Biol 6:2198-2206. 
Uehara Y, Murakami Y, Sugimoto Y, Mizuno S (1989) Mechanism of reversion of Rous Sarcoma virus transformation by herbimycin A reduction of total phosphotyrosine levels due to reduced kinase activity and increased turnover of $\mathrm{p} 60^{\mathrm{v}-\mathrm{srcl}}$. Cancer Res 49:780-785.

VanBerkum MFA, Goodman CS (1995) Targeted disruption of $\mathrm{Ca}^{2+}$. calmodulin signaling in Drosophila growth cones leads to stalls in axon extension and errors in axon guidance. Neuron 14:43-56.

Varnum-Finney B, Reichardt LF (1994) Vinculin-deficient PC12 cell lines extend unstable lamellipodia and filopodia and have a reduced rate of neurite outgrowth. J Cell Biol 127:1071-1084.

Williams EJ, Walsh FS, Doherty P (1994) Tyrosine kinase inhibitors can differentially inhibit integrin-dependent and CAM-stimulated neurite outgrowth. J Cell Biol 124:1029-1037.

Wong S, Reynolds AB, Papkoff J (1992) Platelet activation leads to increased c-src kinase activity and association of c-src with an $85 \mathrm{kDa}$ tyrosine phosphoprotein. Oncogene 7:2407-2415.
Worley T, Holt C (1995) Expression and possible role of pp125FAK in the developing Xenopus retinal projection. Soc Neurosci Abstr 21:1293.

Wu H, Parsons JT (1993) Cortactin, an 80/85-kilodalton pp60sre substrate, is a filamentous actin-binding protein enriched in the cell cortex. J Cell Biol 120:1417-1426.

Wu H, Reynolds AB, Kanner SB, Vines RR, Parsons JT (1991) Identification and characterization of a novel cytoskeleton-associated pp60src substratc. Mol Cell Biol 11:5113-5124.

Xing Z, Chen HC, Nowlen JK, Taylor SJ, Shalloway D, Guan JL (1994) Direct interaction of $v$-Src with the focal adhesion kinase mediated by the Src SH2 domain. Mol Biol Cell 5:413-421.

Yamaki H, Iguchi-Ariga SM, Ariga H (1989) Inhibition of $c-m y c$ gene expression in murine lymphoblastoma cells by geldanamycin and herbimycin, antibiotics of benzoquinoid ansamycin group. J Antibiotics 42:604-610.

Zhao YH, Baker H, Walaas SI, Sudol M (1991) Localization of p62c-yes protein in mammalian neural tissues. Oncogene 6:1725-1733. 